\title{
A new name for an African Aspilia (Compositae: Heliantheae: Ecliptinae)
}

\section{J. Nicholas Hind ${ }^{1}$ (1)}

Summary. Work towards the Compositae for a checklist of the flowering plants of Guinea has shown that Melanthera elegans C.D.Adams belongs in Aspilia Thouars. An earlier 'combination' in the literature was not validly published, the authors also unaware of an earlier combination under the name Aspilia elegans. A new name, Aspilia lisowskiana, is provided for the Guinean species.

Key Words. Asteraceae, checklist, Guinea (Conakry), Lipotriche, Melanthera.

\section{Introduction}

Whilst checking and editing the checklist of Compositae for Guinea, as part of the project 'Important Plant Areas in Guinea' (supported by the Darwin Initiative of the Department of the Environment Food and Rural Affairs (DEFRA), UK government (Project Ref. 23-002)), a number of issues remained to be solved.

The basis of the checklist was the late Stanislav Lisowski's Flora account (Lisowski 2009), and his inclusion of Melanthera elegans C.D.Adams. I have earlier treated the genus Lipotriche DC. (Hind 2014), within which most of the African melantheras belong. However, I commented, under the 'Excluded taxa/names', on the position of Melanthera elegans, and its inclusion in Aspilia Thouars (Hind 2014: 9), noting that Lebrun \& Stork (1997) had, without explanation, included the entity within Aspilia, and provided the name 'Aspilia elegans (C. D. Adams) J.-P. Lebrun \& Stork', a combination that was not validly published. They were probably unaware of the combination in Aspilia of Viguiera elegans Gardner. Bentham \& Hooker (1873: 372) had indicated that Viguiera elegans belonged amongst one of the three series of American taxa that they recognised in Aspilia; no formal combination was made as the epithet was not associated with the generic name. However, Jackson (1893: 217), in providing the name in a Roman typeface and referring back to Bentham \& Hooker's suggestion (as 'elegans, Benth. E Hook. f. Gen. ii. 372.-Bras.'), effectively made the combination Aspilia elegans (Gardner) B.D.Jacks.

Although Wild (1965) included Melanthera elegans in his treatment of the African species, it clearly stood apart, not least by its long ray limbs. In Gerald Pope's personal copy of a reprint of Wild's later revision of African Aspilia (Wild 1966), Pope clearly perceived the generic affinity of this taxon, with the key annotated as 'ligules $2 \mathrm{~cm}+$ elegans' at the couplet leading to ' 15 . [Aspilia] bipartita' (Wild 1966: 201), but Pope took this no further. Wild's treatment of the African 'Melanthera' and Aspilia provided only a limited description of the achenes (Wild 1965: 1; 1966: 197), save indicating that the achenes of both genera were obovoid, compressed and 'pubescent'. However, the distinction between the two genera was more evident in the pappus, that of 'Melanthera' with ' $0-$ c. 12 caducous ... often unequal, stiff barbellate or ciliate bristles', while he recorded in Aspilia a 'laciniate cupule often with (1)-2 (3, 4) barbellate setae in addition.' There are other significant differences that I am aware of in the achene bases, the presence of elaiosomes at the base of the achenes in Aspilia, but their absence in Lipotriche. Adams (1964: 135) was quite explicit about the achenes, noting that they have 'a conspicuous orbicular scale on each side at the base' - an elaiosome. The pappus in 'Melanthera elegans' is indeed a cupule with a 'few minute caducous bristles' (Adams 1964: 135). Since this fully supports the inclusion of Melanthera elegans in Aspilia, a new name is proposed below.

\section{New name}

Aspilia lisowskiana D.J.N.Hind, nom. nov. pro Melanthera elegans C.D.Adams, non Aspilia elegans (Gardner) B.D.Jacks. (Jackson 1893: 217).

http://www.ipni.org/urn:lsid:ipni.org:names:60478261-2

Melanthera elegans C.D.Adams, J. W. African Sci. Assoc. 8 (2): 135 (1963)[Aug. 1964]. Type: 'GuinEA.-[Fouta Djalon] Hollandé Tossékré, [15] October 1956,

Accepted for publication 28 February 2019. Published online 10 April 2019

1 Herbarium, Royal Botanic Gardens, Kew, Richmond, Surrey, TW9 3AE, UK. e-mail: n.hind@kew.org 
Adam 12728 (Holotypus K; Isotypus IFAN); ...' holotype: $\mathrm{K}(000453489)$; isotypes: IFAN, $\mathrm{P}(00072535)$.

'Aspilia elegans (C. D. Adams) J.-P. Lebrun \& Stork', Énum. Pl. Fleurs Afr. Trop. 4: 250 (1997), name not validly published. Note: this 'combination' both lacked the citation of the place of publication of the basionym (i.e. contrary to Art. 41.5 of the Code - Turland et al. 2018), and would have been a later homonym of Aspilia elegans (Gardner) B.D.Jacks. if the place of publication had been cited. Elsewhere in this work, Lebrun \& Stork (1997) clearly indicated new combinations with the abbreviation 'comb. nov.'; such was not the case in this instance.

DISTRIBUTION. Guinea.

CONSERVATION STATUS. Aspilia lisowskiana is in the course of being assessed for its conservation status to support its protection in the wild using the Important Plant Area protocol as set out in Darbyshire et al. (2017). Since there are less than ten locations known, and threats are documented, it is expected to be assessed as Vulnerable using the IUCN system.

\section{Acknowledgements}

The author would like to thank Martin Cheek for inviting me to help with the Compositae in the Guinea checklist, and George Gosline for providing the basic list upon which I worked. Two anonymous referees are thanked for their comments in improving the original draft of this short paper.

Open Access This article is distributed under the terms of the Creative Commons Attribution 4.0 International License (http://creativecommons.org/ licenses/by/4.0/), which permits unrestricted use, distribution, and reproduction in any medium, provided you give appropriate credit to the original author(s) and the source, provide a link to the Creative Commons license, and indicate if changes were made.

\section{References}

Adams, C. D. (1964) [Aug. 1964]. New records of flowering plants in West Africa. VI.-Compositae (Conclusion). J. W. African Sci. Assoc. 8 (2): $134-140$.

Bentham, G. \& Hooker, J. D. (1873). Genera plantarum ad exemplaria imprimis in herbariis Kewensibus servata definita. Vol. 2 (1): Sistens dicotyledonum gamopetalarum ordines VI, CaprifoliaceasCompositas. Lovell Reeve \& Co., Londini.

Darbyshire, I., Anderson, S., Asatryan, A., Byfield, A., Cheek, M., Clubbe, C., Ghrabi, A., Harris, T., Heatubun, C. D., Kalema, J., Mafassouba, S., McCarthy, B., Milliken, W., de Montmollin, B., NicLughadha, E., Onana, J.-M., Saïdou, D., Sârbu, A., Shrestha, K. \& Radford, E. A. (2017). Important Plant Areas: revised selection criteria for a global approach to plant conservation. Biodivers. $\mathcal{E}^{2}$ Conservation 26(8): 1767 - 1800.

Hind, D. J. N. (2014). A synopsis of the African genus Lipotriche (Compositae: Heliantheae: Ecliptinae). Kew Bull. 69 (3)-9528: 1 - 13. https://doi.org/10.1007/ S12225-014-9528-7.

Jackson, B. D. (1893). Index Kewensis: an enumeration of the genera and species of flowering plants from the time of Linnaeus to the year 1885 inclusive together with their authors' names, the works in which they were first published, their native countries and their synonyms compiled at the expense of the late Charles Robert Darwin under the direction of Joseph D. Hooker. Vol. 1[Part 1]. Clarendon Press, Oxford.

Lebrun, J.-P. \& Stork, A. L. (1997). Énumération des plantes à fleurs d'Afrique Tropical. Vol. IV. Gamopétales: Clethraceae à Lamiaceae. Conservatoire et Jardin Botaniques de la Ville de Genève, Genève.

$\nmid$ Lisowski, S. (2009). Flore (Angiospermes) de la République de Guinée. Première partie (texte). Scripta Bot. Belgica 41: [i] - vii, 1 - 517. [Asteraceae: $72-96$.

Turland, N. J., Wiersama, J. H., Barrie, F. R., Greuter, W., Hawksworth, D. L., Herendeen, P. S., Knapp, S., Kusber, W.-H., Li, D.-Z., Marhold, K., May, T. W., McNeill, J., Monro, A. M., Prado, J., Price, M. J. \& Smith, G. F. (eds) (2018). International Code of Nomenclature for algae, fungi, and plants (Shenzhen Code) adopted by the Nineteenth International Botanical Congress, Shenzhen, China, July 2017. Regnum Veg. 159. Koeltz Botanical Books, Glashütten. https://doi.org/10.12705/ Code. 2018

Wild, H. (1965). The African species of the genus Melanthera Rohr. Kirkia 5(1): 1 - 17. (1966). The African species of the genus Aspilia Thouars. Kirkia 5(2): 197 - 228.

\section{Publisher's Note}

Springer Nature remains neutral with regard to jurisdictional claims in published maps and institutional affiliations. 